Fetal Diagnosis and Therapy

\title{
Fetal Treatment 2017: The Evolution of Fetal Therapy Centers - A Joint Opinion from the International Fetal Medicine and Surgical Society (IFMSS) and the North American Fetal Therapy Network (NAFTNet)
}

\author{
Anita J. Moon-Grady ${ }^{a, b}$ Ahmet Baschat ${ }^{e}$ Darrell Cass $^{f}$ Mahesh Choolani $^{g}$ \\ Joshua A. Copel ${ }^{\text {h }}$ Timothy M. Crombleholme ${ }^{i}$ Jan Deprest ${ }^{j-1}$ \\ Stephen P. Emery ${ }^{m}$ Mark I. Evans ${ }^{n}$ Francois I. Luks ${ }^{\circ}$ Mary E. Norton ${ }^{a, c}$ \\ Greg Ryan $^{p}$ Kuojen Tsao ${ }^{q}$ Ross Welch ${ }^{r}$ Michael Harrison ${ }^{a}$ d

\begin{abstract}
${ }^{a}$ The Fetal Treatment Center, UCSF Benioff Children's Hospital, and Departments of b Pediatrics, ${ }^{\mathrm{C} O b s t e t r i c s,}$ Gynecology, and Reproductive Sciences, and d Surgery, University of California San Francisco, San Francisco, CA, e Johns Hopkins Center for Fetal Therapy, Baltimore, MD, and fTexas Children's Fetal Center and Michael E. DeBakey Department of Surgery, Baylor College of Medicine, Houston, TX, USA; ${ }^{9}$ Department of Obstetrics and Gynaecology, National University of Singapore, Singapore; ' Department of Obstetrics, Gynecology and Reproductive Sciences, Yale School of Medicine, New Haven, CT, and 'Colorado Fetal Care Center, Colorado Institute for Maternal and Fetal Health, Division of Pediatric General, Thoracic and Fetal Surgery, University of Colorado School of Medicine, Children's Hospital Colorado, Aurora, CO, USA; 'ंDepartment of Obstetrics and Gynecology, University Hospitals Leuven, and kDepartment of Development and Regeneration, Faculty of Medicine, KU Leuven, Leuven, Belgium; 'Research Department of Maternal Fetal Medicine, Institute of Women's Health, University College London, London, UK; ${ }^{m}$ Department of Obstetrics, Gynecology and Reproductive Sciences, University of Pittsburg School of Medicine, Pittsburg, PA, n'Department of Obstetrics and Gynecology, Mt. Sinai School of Medicine, New York, NY, and ${ }^{\circ}$ Division of Pediatric Surgery and Program in Fetal Medicine, Alpert Medical School of Brown University, Providence, RI, USA; ${ }^{P}$ Fetal Medicine Program, Mount Sinai Hospital, University of Toronto, Toronto, ON, Canada; ${ }^{q}$ Children's Memorial Hermann Hospital and Department of Pediatric Surgery, University of Texas Health Science Center at Houston, Houston, TX, USA; 'rFetal Medicine Unit, Derriford Hospital, Plymouth, UK
\end{abstract}

\section{Keywords}

Fetal therapy - Advances in care - Fetal therapy centers . Maternal autonomy and safety · State of the art · Ethics

\begin{abstract}
More than 3 decades ago, a small group of physicians and other practitioners active in what they called "fetal treatment" authored an opinion piece outlining the current status and future challenges anticipated in the field. Many ad-
\end{abstract}

\section{KARGER}

E-Mail karger@karger.com

www.karger.com/fdt
(C) 2017 S. Karger AG, Basel vances in maternal, neonatal, and perinatal care and diagnostic and therapeutic modalities have been made in the intervening years, yet a thoughtful reassessment of the basic tenets put forth in 1982 has not been published. The present effort will aim to provide a framework for contemporary redefinition of the field of fetal treatment, with a brief discussion of the necessary minimum expertise and systems base

Presented at the 35th Annual Meeting of the International Fetal Medicine and Surgical Society, August 2-7, 2016, Kasane, Botswana.
Anita J. Moon-Grady, MD, FAAP, FACC

Division of Cardiology, Department of Pediatrics, The Fetal Treatment Center UCSF Benioff Children's Hospital, 1855 4th Street, 2nd floor, room A2432 University of California, San Francisco, CA 94158 (USA)

E-Mail Anita.moongrady@ ucsf.edu 
for the provision of different types of interventions for both the mother and fetus. Our goal will be to present an opinion that encourages the advancement of thoughtful practice, ensuring that current and future patients have realistic access to centers with a range of fetal therapies with appropriate expertise, experience, and subspecialty and institutional support while remaining focused on excellence in care, collaborative scientific discovery, and maternal autonomy and safety.

(c) 2017 S. Karger AG, Basel

\section{Introduction}

In 1982, practitioners from a dozen institutions in 5 countries gathered to discuss the emerging field of "fetal therapy" - a new approach to prenatally diagnosed congenital anomalies potentially amenable to intervention before birth - with the goal of changing the natural history of diseases including hydrocephalus, obstructive uropathy, and pulmonary hypoplasia secondary to a congenital diaphragmatic hernia $(\mathrm{CDH})$. Their consensus regarding the state of the art and basic tenets and challenges regarding the science and ethics of interventions which involved 2 patients in order to benefit the unborn child were published as a short letter in the New England Journal of Medicine later that year [1]. Over the last 3 decades, the field has progressed rapidly [2-4]. Fetal therapy centers (FTCs) have developed worldwide as a consequence of advances in prenatal diagnosis, fetal imaging, instrumentation, interventional techniques, and expertise. Our understanding of maternal-fetal pathophysiology in a broad range of conditions has also expanded greatly. Examples include ultrasound-guided procedures, such as fetal blood sampling or intrauterine transfusion, vesico- or thoraco-amniotic shunt placement [5], cardiac balloon valvuloplasty and stent placement [6], vascular occlusion procedures (bipolar electrocautery, radiofrequency ablation, interstitial laser ablation, or thrombogenic coil injection) for complex monochorionic twin pregnancies, hydropic lung lesions or sacrococcygeal teratomas, and prenatal stem cell transplantation [7]. Fetoscopic techniques have been developed for laser treatment of twin-twin transfusion syndrome (TTTS) [8], tracheal balloon occlusion for $\mathrm{CDH}$ [9], and ultrasound-guided fetal delivery of mesenchymal stem cells [7]. Open fetal surgical techniques predominantly for myelomeningocele [10] and also for some congenital pulmonary airway malformations or sacrococcygeal teratomas have been refined. Finally, ex utero intrapartum treatment has been developed for the delivery of neonates with major obstructive airway anomalies [11-13].

Despite these advances, the basic tenets (Table 1) applied to fetal treatment have not been reevaluated in a scientific forum, although some, e.g., placental laser ablation for monochorionic twin pregnancies with TTTS, have departed from the original dictum that "only singletons should be considered as candidates for fetal therapy." As both diagnostic and surgical techniques have evolved, we have begun to reconsider the role of fetal therapy in conditions that were hitherto under a moratorium, e.g., fetal aqueductal stenosis. As the focus of fetal therapy has shifted from not just enabling the survival of a neonate with an otherwise lethal condition to improving its quality of life (e.g., fetal myelomeningocele repair), concerns have arisen regarding the practice of fetal medicine in the context of a maternal intervention. In 2011, a joint statement of the American College of Obstetricians and Gynecologists and the American Academy of Pediatrics $[14,15]$ discussed many issues in this emerging field, emphasizing the principles of maternal autonomy, careful assessment of the risk-benefit relationship, advocacy for both mother and fetus in the context of research and innovation, avoidance of unintentional coercion [16], and the need for collaborative models and centers of excellence. In essence, fetal therapy presents challenges to observing the ethical principles of justice, nonmaleficence, and beneficence. As the inherent duality of the maternal-fetal dyad potentially puts optimizing fetal outcome in conflict with what is best for maternal health, FTCs have an ethical obligation to carefully consider both maternal and fetal wellbeing when any form of in utero intervention is being contemplated. Thus, 34 years after the basic tenets of fetal treatment were first published, it is evident that a new approach should be defined that takes into account the numerous advances in the field, the shift in the ethical paradigm of fetal intervention to include the reduction not only of mortality but also of significant morbidity, and the clear obligations that all health-care providers have in caring for both the mother and her fetus [1]. In response, members of both the North American Fetal Therapy Network (NAFTNet) and the International Fetal Medicine and Surgical Society (IFMSS) have convened to produce the present statement.
242

Fetal Diagn Ther 2017;42:241-248

DOI: $10.1159 / 000475929$
Moon-Grady et al. 
Table 1. Criteria for the advancement of fetal therapy: 1982 [1] versus the present era

\begin{tabular}{lll}
\hline Topic & Historical viewpoint & Current era considerations \\
\hline $\begin{array}{l}\text { Nature of the } \\
\text { disorder }\end{array}$ & $\begin{array}{l}\text { The disorder must be of a significant nature } \\
\text { and should be a simple structural defect that } \\
\text { interferes with organ development, whose } \\
\text { alleviation might allow fetal development to } \\
\text { proceed normally }\end{array}$ & $\begin{array}{l}\text { As the spectrum of conditions for which fetal therapy is offered } \\
\text { and the goals of therapy have evolved, goals of fetal treatment } \\
\text { may begin to alter (e.g., MMC, OI, cardiac procedures) or to } \\
\text { cure (TTTS). In some cases, there may be benefit to one fetus } \\
\text { with no benefit to the other (e.g., RFA or laser in complicated } \\
\text { monochorionic twin or triplet pregnancies) }\end{array}$
\end{tabular}

\begin{tabular}{ll}
\hline $\begin{array}{l}\text { Reporting } \\
\text { requirements }\end{array}$ & $\begin{array}{l}\text { All case material should be reported, } \\
\text { regardless of outcome, to a fetal treatment } \\
\text { registry or in the medical literature (or both) }\end{array}$
\end{tabular}

Several self-imposed registry efforts are underway, but mandatory reporting is not in effect; clinical trials are suffering from geographic and regulatory barriers. Infrastructure for reporting largely lacks funding and resources except on a voluntary basis

Appropriateness The fetus should be a singleton without criteria concomitant anomalies according to advanced ultrasonographic examination and amniocentesis for karyotype, $\alpha$-feto protein, and cultures
Effective therapies for multiple pregnancies with or without an "innocent bystander" (e.g., TTTS, selective reduction of an anomalous twin) may be considered if therapy will prolong and/ or improve outcome of that pregnancy. Prenatal genetic screening and diagnosis have evolved exponentially; current options include diagnostic chromosomal microarray analysis and screening via noninvasive prenatal testing for common aneuploidies. The significance of abnormal testing in this context is unclear. The introduction of whole exome sequencing into clinical practice will undoubtedly further complicate this issue. There may also be genetic conditions, such as OI, and some hemoglobinopathies that would benefit from novel stem cell therapies

\begin{tabular}{ll}
\hline Candidate & Selection for treatment must be based on \\
diseases & careful clinical evaluation and sound \\
knowledge of the natural history of the fetal \\
disease; intervention can be ethically justified \\
only if there is a reasonable probability of \\
benefit
\end{tabular}

Improvements in prenatal diagnosis have improved our ability to diagnose fetal conditions. Our understanding of fetal physiology and pathophysiology has advanced considerably. Predictive measures of morbidity and mortality are being developed to help providers weigh the risks and benefits for the mother and her fetus. These have guided the types of fetal therapy presently offered. Long-term follow-up studies are lacking for most fetal therapies. Animal models do not adequately reflect the human fetal phenotype for many diseases, and extrapolation from animal models must be done with caution

\begin{tabular}{ll}
\hline $\begin{array}{l}\text { Center } \\
\text { infrastructure }\end{array}$ & $\begin{array}{l}\text { There should be access to a level III high-risk } \\
\text { obstetric unit and bioethical and psychosocial } \\
\text { counseling }\end{array}$
\end{tabular}

Checks and A multidisciplinary team, including a
balances perinatal obstetrician experienced in fetal diagnosis and intrauterine transfusion, an ultrasonographer experienced in the diagnosis of fetal anomalies, and a pediatric surgeon and neonatologist who will manage the infant after birth, should concur on the plan for innovative treatment and obtain approval of an institutional review board
Levels of care for the newborn and for the pregnant woman have been refined and redefined [26], and the need for a more complex, structured support system has been specifically stated $[14,15]$

Multidisciplinary teams should be tailored to the defect(s) being treated and will usually include a variety of disciplines. These are likely to include some or all of: qualified maternal-fetal medicine specialist(s), geneticists, pediatric surgical specialists, obstetric anesthesiologists, and diagnostic and nursing/midwifery services. An appropriate mechanism for informed consent and oversight with a formal process for reporting and review must be in place. Educational and quality improvement infrastructure is preferable. Ethical oversight, participation in registries, and transparent counseling and reporting are crucial for centers proposing experimental or innovative procedures that pose any risk to the mother. Parents must be counseled regarding any alternative therapies and the options of pregnancy termination and neonatal palliative care where appropriate 
Table 1 (continued)

\begin{tabular}{lll}
\hline Topic & Historical viewpoint & Current era considerations \\
\hline $\begin{array}{l}\text { Goals of } \\
\text { treatment }\end{array}$ & $\begin{array}{l}\text { The family should be fully counseled about } \\
\text { risks and benefits and should agree to } \\
\text { treatment, including long-term follow-up to } \\
\text { determine efficacy }\end{array}$ & $\begin{array}{l}\text { There is increasing focus on short- and long-term effects of fetal } \\
\text { therapy on maternal reproductive health. Issues are becoming } \\
\text { increasingly complex as the goals of fetal treatment move from } \\
\text { primarily achieving survival to decreasing morbidity and } \\
\text { improving the functional and neurodevelopmental outcome of } \\
\text { the child }\end{array}$ \\
\hline $\begin{array}{ll}\text { Maternal safety } \\
\text { and autonomy }\end{array}$ & $\begin{array}{l}\text { Implied but not stated: maternal risks should } \\
\text { be minor and acceptable to mother and } \\
\text { family }\end{array}$ & $\begin{array}{l}\text { Maternal expectations have evolved. In contrast to 30 years ago, } \\
\text { pregnant women now expect fetal abnormalities to be diagnosed } \\
\text { prenatally, and they also expect that for some abnormalities the } \\
\text { option for fetal treatment (where available and evidence-based) } \\
\text { will be available. As fetal therapy has become more available, } \\
\text { uptake has become greater. In addition, some are willing to } \\
\text { incur greater personal risk in an effort to improve the prognosis } \\
\text { for their fetus. Care must be taken to avoid the pitfalls in } \\
\text { perception - just because a procedure is offered within or } \\
\text { outside a research protocol does not imply proven efficacy }\end{array}$ \\
& &
\end{tabular}

MMC, myelomeningocoele; OI, osteogenesis imperfecta; TTTS, twin-twin transfusion syndrome; RFA, radiofrequency ablation.

\section{Setting Expectations in the Current Era}

With all technologies, there are 2 distinct evolutionary phases. First, a "development" phase in which a small number of investigators - usually, but not necessarily, at academic medical centers - pioneers a new approach, evaluates complications, refines techniques, tests, and possibly patents, and publishes their findings. Over time, the technology is recognized, and clinical demand increases beyond the capability of the originators to reasonably perform all cases or tests. At that point, there is a "diffusion" phase as the technology expands to multiple locations to give increasing numbers of patients the benefits of the new approach. During this phase, utilization rapidly expands but is often paralleled by a corresponding increase in procedure-related complications. Eventually, experience expands and performance improves across the board. There is a complicated balance between the pioneers' interests in ensuring the success of new approaches and the potential benefits to patients, while at the same time not being overly protective or exclusionary in controlling "trade" in an open market.

Several fetal interventions that were once innovative (including those for TTTS, myelomeningocele, and $\mathrm{CDH}$ ) have been evaluated in randomized clinical trials $[8-10,17]$, whereas others (balloon valvuloplasty for fetal critical aortic stenosis and intrauterine stem cell therapy for osteogenesis imperfecta) are currently either under- going trials or are being included in registries. These successes make it probable that as technology advances, the field of fetal therapy may evolve at a pace that outstrips our ability to anticipate or initiate regulation in the field. As practitioners, we must take the initiative to set standards of care for the performance of all fetal procedures in order to achieve the most favorable outcomes, ensure maternal and fetal safety, minimize complications, and provide appropriate resources for their management if complications occur. In addition to proposing a modification to the original philosophical and systems principles (Table 1), we maintain that there should be expectations for the resources, expertise, credentialing, and infrastructure for an organization, medical staff, and personnel who work in a FTC (Table 2). Additionally, since many fetal diseases represent medically and ethically complex situations, we strongly advocate the development of multidisciplinary therapy teams as appropriate.

\section{Scope and Definitions Pertaining to Fetal Treatment}

Our proposed modification assumes that all prenatal interventions should be in compliance with the basic principles of fetal therapy (Table 1). Within this scope, fetal therapy can be divided into medical or surgical approaches that aim to achieve a complete prenatal cure, alleviate severe pediatric developmental or functional de- 
Table 2. Necessary components for the provision of fetal care in the current era

\begin{tabular}{|c|c|c|}
\hline Component & Function & Facility where services are rendered \\
\hline $\begin{array}{l}\text { Prenatal diagnostic and management } \\
\text { services, including fetal ultrasound and } \\
\text { MRI and MFM expertise }\end{array}$ & $\begin{array}{l}\text { Accurate diagnosis of fetal condition } \\
\text { Prenatal interventions } \\
\text { Coordination of prenatal care path }\end{array}$ & $\begin{array}{l}\text { Prenatal imaging center (fetal therapy } \\
\text { center or contracted) }\end{array}$ \\
\hline $\begin{array}{l}\text { Obstetric services including nursing/ } \\
\text { midwifery }\end{array}$ & $\begin{array}{l}\text { Management of maternal and obstetric } \\
\text { conditions, including pregnancy termination }\end{array}$ & $\begin{array}{l}\text { Operating room } \\
\text { Inpatient and outpatient services } \\
\text { Labor and delivery }\end{array}$ \\
\hline Nurse coordinators & $\begin{array}{l}\text { Care coordination, resource (for patients and } \\
\text { providers), education }\end{array}$ & Inpatient and outpatient \\
\hline Obstetric anesthesia & $\begin{array}{l}\text { Maternal management during obstetric or } \\
\text { fetal interventions }\end{array}$ & $\begin{array}{l}\text { Operating room } \\
\text { Labor and delivery }\end{array}$ \\
\hline Genetics & $\begin{array}{l}\text { Accurate diagnosis of fetal condition } \\
\text { Incorporation of additional testing } \\
\text { Counseling regarding long-term implications } \\
\text { of genetic disease }\end{array}$ & $\begin{array}{l}\text { Inpatient and outpatient services, } \\
\text { institutional or under contract }\end{array}$ \\
\hline Neonatology, including nursing & $\begin{array}{l}\text { Prenatal consultation } \\
\text { Peripartum and postdelivery care } \\
\text { ECMO services }\end{array}$ & Intensive care nursery \\
\hline Pediatric surgery & $\begin{array}{l}\text { Prenatal consultation, prenatal interventional } \\
\text { and postdelivery management }\end{array}$ & $\begin{array}{l}\text { Operating room, inpatient and outpatient } \\
\text { services }\end{array}$ \\
\hline Pediatric anesthesia & $\begin{array}{l}\text { Fetal/neonatal management during surgical } \\
\text { interventions }\end{array}$ & Operating room \\
\hline $\begin{array}{l}\text { Pediatric cardiology (invasive and } \\
\text { non-invasive imaging) }\end{array}$ & $\begin{array}{l}\text { Prenatal diagnosis, postpartum management } \\
\text { Fetal hemodynamic monitoring during complex } \\
\text { procedures }\end{array}$ & Inpatient and outpatient services \\
\hline $\begin{array}{l}\text { Pediatrics, including subspecialists } \\
\text { and nursing }\end{array}$ & $\begin{array}{l}\text { Prenatal consultation } \\
\text { Postdelivery management } \\
\text { Long-term developmental follow-up }\end{array}$ & Inpatient and outpatient services \\
\hline Adult medicine and critical care & $\begin{array}{l}\text { Consultation, assumption of maternal care for } \\
\text { select complications of pregnancy or treatment }\end{array}$ & $\begin{array}{l}\text { Fetal therapy center in close proximity } \\
\text { (if the center is in a children's hospital) }\end{array}$ \\
\hline Social work and spiritual support & $\begin{array}{l}\text { Coordination of social services } \\
\text { Patient advocacy } \\
\text { Perinatal loss support and support for } \\
\text { pregnancy termination }\end{array}$ & $\begin{array}{l}\text { Inpatient and outpatient services, available } \\
\text { to patient and family/support persons }\end{array}$ \\
\hline $\begin{array}{l}\text { Interpreter and cultural diversity } \\
\text { specialist }\end{array}$ & $\begin{array}{l}\text { Consultation, consent, and follow-up services, } \\
\text { especially when multiple therapeutic options } \\
\text { are being entertained }\end{array}$ & $\begin{array}{l}\text { Inpatient and outpatient services, available } \\
\text { to patient and family/support persons }\end{array}$ \\
\hline Palliative care & $\begin{array}{l}\text { Palliative postdelivery care, perinatal hospice } \\
\text { services }\end{array}$ & $\begin{array}{l}\text { Various settings including hospital and } \\
\text { home }\end{array}$ \\
\hline Medical ethicist & $\begin{array}{l}\text { Consultation and oversight as needed, for } \\
\text { research and clinical arenas }\end{array}$ & Institutional or centralized \\
\hline Institutional review board & $\begin{array}{l}\text { Oversight of experimental and research-related } \\
\text { interventions }\end{array}$ & Institutional or centralized \\
\hline GMP facility & $\begin{array}{l}\text { Production of GMP-grade stem cells for fetal } \\
\text { intravenous infusion }\end{array}$ & $\begin{array}{l}\text { Prenatal imaging center (fetal therapy } \\
\text { center or contracted) }\end{array}$ \\
\hline $\begin{array}{l}\text { Database and information technology } \\
\text { support services }\end{array}$ & $\begin{array}{l}\text { Reporting, data collection and sharing, research } \\
\text { and quality improvement arenas }\end{array}$ & Institutional \\
\hline
\end{tabular}

MRI, magnetic resonance imaging; MFM, maternal-fetal medicine; ECMO, extracorporeal membrane oxygenation; GMP, good manufacturing practices. 
ficiencies, or optimize the fetal transition to extrauterine life. Fetal interventions are classified broadly to include the following: (1) ultrasound-guided needle procedures (e.g., fetal blood sampling, intrauterine transfusion, shunts, balloon valvuloplasty, and radiofrequency ablation or interstitial laser coagulation); (2) fetoscopic procedures (placental laser ablation for TTTS, umbilical cord occlusion, tracheal balloon occlusion, amniotic band release, laser ablation for lower urinary tract obstruction, and myelomeningocele repair); (3) open fetal surgery (myelomeningocele repair or resection of some lung masses or teratomas), and (4) ex utero intrapartum treatment procedures for the management of anomalies compromising the newborn's airway. Though some overlap may exist in the procedures that are offered for a given condition, in our proposed modification, "open" fetal surgery refers to any procedure requiring a hysterotomy in contrast to those involving only the insertion of a fetoscope.

A FTC is more difficult to define, but it should at a minimum be able to provide advanced imaging services, a variety of established fetal therapies and innovative approaches to fetal disease, and possibly conduct, facilitate, or participate in research if appropriate to the setting within its particular health-care delivery system. A FTC may be either a freestanding self-contained center or may draw on expertise and resources from physically separate facilities to provide consultation or therapy and to manage any fetal or maternal complications (including pregnancy termination if this is an option) that may result from the fetal condition or the therapy. It may be more logical to consider the necessary components in the context of diseases that are treated and services that are provided (Table 2), with a pragmatic approach to inclusion of components suggested in the context of services provided at any given center.

\section{Research Trials, Registries, Regionalization, and Planning for the Future}

Fetal interventions should be subjected to scientific scrutiny by inclusion in institutional, national, regional, or international trials and registries. Initially, the pioneers in this area recognized the need for transparency in reporting outcomes (Table 1). To some extent, this has been realized, albeit sporadically, though efforts have largely focused on disease-specific clinical trials or registries. To date, randomized controlled trials for laser therapy for TTTS, open repair of fetal myelomeningocele, early treat- ment for acardiac twins, and tracheal occlusion for fetal $\mathrm{CDH}$ have been completed or are underway, and registries exist for fetal cardiac interventions [6], post-trial myelomeningocele repair [18], and fetal monochorionic twin complications and interventions. However, many fetal procedures are not being evaluated rigorously, and none of the registries are public or funded beyond their initial startup costs. One attempt to address this need is being made within the NAFTNet, a consortium of over 30 medical centers in the United States and Canada, which collaborate on research in fetal diseases. Reporting a center's clinical experience is a prerequisite for membership, and funding is through institutional membership dues.

To assure both access to care for patients and an adequate patient volume to maintain expertise for practitioners and teams, more attention needs to be focused on resource planning, publication, dissemination and quality benchmarking of outcomes and complications, public reporting, and the larger context of facilitating patient access to appropriate care. There is evidence to support the regionalization of subspecialty care in other areas of medicine [19-22]. In certain types of fetal therapy (e.g., laser for TTTS and intrauterine transfusion for red blood cell alloimmunization), the benefits of regionalization of care and concentration of volume have been clearly demonstrated [13, 23-25], but in others, support comes from expert opinion only [26]. In fact, it is equally clear that mere volume and/or individual experience do not guarantee excellence in clinical outcomes when center-based medicine is examined (e.g., the "Bristol experience" in which imposed regionalization of congenital cardiac care actually led to worse outcomes for children in the UK) [27]. Nevertheless, it seems reasonable to assume that regionalization of care for rare conditions and procedures would allow centers not only to maintain adequate volume and expertise for the fetal interventions per se, but also to develop crucial supportive components of care, such as evaluation, counseling, and education. Eventually, formalized training and credentialing programs - similar to those regarding nuchal translucency screening or cervical length screening, for instance - might be a reasonable goal. Although often politically daunting, task forces to develop formal recommendations regarding the number and geographic distribution of FTCs should be formed to address these issues as well as the overarching issue of patient access to care.

We must also plan to train the next generation of fetal therapists. There is currently no formal international program for training in fetal therapy. Several centers in the
246

Fetal Diagn Ther 2017;42:241-248 DOI: $10.1159 / 000475929$
Moon-Grady et al. 
United States, Canada, UK, and Europe offer nonaccredited fetal intervention "fellowships" that can be entered after completion of formal training in either pediatric surgery or maternal fetal medicine. Many physicians then enter into an even less well-defined "apprenticeship" model in which junior faculty are gradually allowed to develop the requisite skill set to operate independently. Systems should be developed that allow for more formalized training in fetal intervention, and minimum standards for proficiency - which will vary with provider role and type of procedure - should be discussed in an open forum with practitioners, training program administrators, and graduate medical education or the equivalent officials. These efforts should begin formally as soon as reasonably feasible. The best framework for this effort and the appropriate participants have not been determined, but a formal dialog among major centers in the Americas, Europe, and Asia has already begun.

\section{Importance of Oversight}

Centers that perform invasive fetal procedures should report their maternal, fetal, and newborn outcomes as transparently as possible, for example under the auspices of clinical trials or in registries. For certain procedures (particularly those still considered as innovative or under research), a nonpartisan, objective, multidisciplinary institutional oversight committee is important. Such committees should include individuals not directly involved in clinical care of the patients and could consist of maternal-fetal medicine specialist(s), hospital ethicist(s), pediatric surgeon(s), neonatologist(s), medical staff office chief of staff, and other members as necessary, including patients themselves. These committees may sometimes also serve as reviewing bodies for the purposes of institutional or ethical review board presubmission review for research proposals or clinical trials.

\section{Summary of Recommendations}

Rapid evolution in the field of fetal therapy has led to the need to revise the initial guiding principles set forth by Harrison et al. [1] more than 3 decades ago. FTCs are ethically obliged to consider both maternal and fetal wellbeing and complications when any fetal intervention is being considered. Centers are also obliged to ensure that appropriate training, credentialing, infrastructure, and institutional support and oversight are in place. A

Defining Fetal Therapy Centers core organizational structure and expertise level will be essential for all fetal therapeutic procedures and for maternal care. Additional infrastructure and subspecialty availability will be necessary for others. Rather than hindering innovation, appropriate and thoughtful preparation and requirements for infrastructural support and commitment should encourage advancement of the field in the decades to come. In all settings, mechanisms for the provision of training, regulation, and oversight should be developed. Multidisciplinary, collaborative, and multi-institutional experience sharing in the form of registries and collaborative multicenter prospective research are essential to continue moving this field forward. As the field matures, the development of robust and sustainable training programs will be essential for continual development of fetal therapy. The most appropriate and reasonable balance between safe innovation, development of new high-quality centers, acquisition and maintenance of skills, and realistic patient access to care within or even outside of highly specialized centers must be carefully considered.

\section{Condensation}

A conceptual framework is presented for redefining the field of fetal treatment, including necessary expertise and systems base for provision of interventions involving mother and fetus.

\section{Acknowledgements}

We would like to acknowledge Pamela Derish in the UCSF Department of Surgery for her assistance in preparing this manuscript.

NAFTNet is supported by grant \#5R13HD059293-05 from the Eunice Kennedy Shriver National Institute of Child Health and Human Development.

\section{Disclosure Statement}

M.E.N. was a co-principal investigator for clinical trial NCT0145167 sponsored by Ariosa Diagnostics. Her institution received unrestricted research funding for her research program from Natera. The other authors report no conflicts of interest. 


\section{References}

1 Harrison MR, Filly RA, Golbus MS, Berkowitz RL, Callen PW, Canty TG, Catz C, Clewell WH, Depp R, Edwards MS, Fletcher JC, Frigoletto FD, Garrett WJ, Johnson ML, Jonsen A, De Lorimier AA, Liley WA, Mahoney MJ, Manning FD, Meier PR, Michejda M, Nakayama DK, Nelson L, Newkirk JB, Pringle K, Rodeck C, Rosen MA, Schulman JD: Fetal treatment 1982. N Engl J Med 1982;307:1651-1652.

2 Quintero RA, Reich H, Puder KS, Bardicef M, Evans MI, Cotton DB, Romero R: Brief report: umbilical-cord ligation of an acardiac twin by fetoscopy at 19 weeks of gestation. $\mathrm{N}$ Engl J Med 1994;330:469-471.

3 Harrison MR, Adzick NS, Longaker MT, Goldberg JD, Rosen MA, Filly RA, Evans MI, Golbus MS: Successful repair in utero of a fetal diaphragmatic hernia after removal of herniated viscera from the left thorax. N Engl J Med 1990;322:1582-1584.

4 Harrison MR, Golbus MS, Filly RA, Callen PW, Katz M, de Lorimier AA, Rosen M, Jonsen AR: Fetal surgery for congenital hydronephrosis. N Engl J Med 1982;306:591-593.

5 Manning FA, Harrison MR, Rodeck C: Catheter shunts for fetal hydronephrosis and hydrocephalus. Report of the International Fetal Surgery Registry. N Engl J Med 1986;315: 336-340.

6 Moon-Grady AJ, Morris SA, Belfort M, Chmait R, Dangel J, Devlieger R, Emery S, Frommelt M, Galindo A, Gelehrter S, Gembruch U, Grinenco S, Habli M, Herberg U, Jaeggi E, Kilby M, Kontopoulos E, Marantz P, Miller O, Otano L, Pedra C, Pedra S, Pruetz J, Quintero R, Ryan G, Sharland G, Simpson J, Vlastos E, Tworetzky W, Wilkins-Haug L, Oepkes D: International Fetal Cardiac Intervention Registry: a worldwide collaborative description and preliminary outcomes. J Am Coll Cardiol 2015;66:388-399.

7 Gotherstrom C, Westgren M, Shaw SW, Astrom E, Biswas A, Byers PH, Mattar CN, Graham GE, Taslimi J, Ewald U, Fisk NM, Yeoh AE, Lin JL, Cheng PJ, Choolani M, Le Blanc K, Chan JK: Pre- and postnatal transplantation of fetal mesenchymal stem cells in osteogenesis imperfecta: a two-center experience. Stem Cells Transl Med 2014;3:255-264.

8 Senat MV, Deprest J, Boulvain M, Paupe A, Winer N, Ville Y: Endoscopic laser surgery versus serial amnioreduction for severe twinto-twin transfusion syndrome. $\mathrm{N}$ Engl J Med 2004;351:136-144.

9 Harrison MR, Keller RL, Hawgood SB, Kitterman JA, Sandberg PL, Farmer DL, Lee H, Filly RA, Farrell JA, Albanese CT: A randomized trial of fetal endoscopic tracheal occlusion for severe fetal congenital diaphragmatic hernia. N Engl J Med 2003;349:1916-1924.

10 Adzick NS, Thom EA, Spong CY, Brock JW 3rd, Burrows PK, Johnson MP, Howell LJ, Farrell JA, Dabrowiak ME, Sutton LN, Gupta N, Tulipan NB, D'Alton ME, Farmer DL; MOMS Investigators: A randomized trial of prenatal versus postnatal repair of myelomeningocele. N Engl J Med 2011;364:993-1004.

11 Liechty KW, Crombleholme TM, Flake AW, Morgan MA, Kurth CD, Hubbard AM, Adzick NS: Intrapartum airway management for giant fetal neck masses: the EXIT (ex utero intrapartum treatment) procedure. Am J Obstet Gynecol 1997;177:870-874.

12 Mychaliska GB, Bealer JF, Graf JL, Rosen MA, Adzick NS, Harrison MR: Operating on placental support: the ex utero intrapartum treatment procedure. J Pediatr Surg 1997;32: 227-230; discussion 230-221.

13 Ryan G, Somme S, Crombleholme TM: Airway compromise in the fetus and neonate: prenatal assessment and perinatal management. Semin Fetal Neonatal Med 2016;21: 230-239.

14 American College of Obstetricians Gynecologists, Committee on Ethics; American Academy of Pediatrics, Committee on Bioethics: Maternal-fetal intervention and fetal care centers. Pediatrics 2011;128:e473-e478.

15 American College of Obstetricians Gynecologists, Committee on Ethics; American Academy of Pediatrics, Committee on Bioethics: Committee opinion No. 501: maternal-fetal intervention and fetal care centers. Obstet Gynecol 2011;118:405-410.

16 Appelbaum PS, Roth LH, Lidz CW, Benson P, Winslade W: False hopes and best data: consent to research and the therapeutic misconception. Hastings Cent Rep 1987;17:20-24.

17 Crombleholme TM, Shera D, Lee H, Johnson M, D'Alton M, Porter F, Chyu J, Silver R, Abuhamad A, Saade G, Shields L, Kauffman $\mathrm{D}$, Stone J, Albanese CT, Bahado-Singh R, Ball RH, Bilaniuk L, Coleman B, Farmer D, Feldstein V, Harrison MR, Hedrick H, Livingston J, Lorenz RP, Miller DA, Norton ME, Polzin WJ, Robinson JN, Rychik J, Sandberg PL, Seri I, Simon E, Simpson LL, Yedigarova $\mathrm{L}$, Wilson RD, Young B: A prospective, randomized, multicenter trial of amnioreduction versus selective fetoscopic laser photocoagulation for the treatment of severe twin-twin transfusion syndrome. Am J Obstet Gynecol 2007; 197:396.e391-e399.

18 Moise KJ Jr, Moldenhauer JS, Bennett KA, Goodnight W, Luks FI, Emery SP, Tsao K, Moon-Grady AJ, Moore RC, Treadwell MC,
Vlastos EJ, Wetjen NM: Current selection criteria and perioperative therapy used for fetal myelomeningocele surgery. Obstet Gynecol 2016;127:593-597.

19 Wright JD, Herzog TJ, Siddiq Z, Arend R, Neugut AI, Burke WM, Lewin SN, Ananth $\mathrm{CV}$, Hershman DL: Failure to rescue as a source of variation in hospital mortality for ovarian cancer. J Clin Oncol 2012;30:39763982.

20 Birkmeyer JD, Stukel TA, Siewers AE, Goodney PP, Wennberg DE, Lucas FL: Surgeon volume and operative mortality in the United States. N Engl J Med 2003;349:2117-2127.

21 Birkmeyer JD, Siewers AE, Marth NJ, Goodman DC: Regionalization of high-risk surgery and implications for patient travel times. JAMA 2003;290:2703-2708.

22 Grayson AD, Moore RK, Jackson M, Rathore S, Sastry S, Gray TP, Schofield I, Chauhan A, Ordoubadi FF, Prendergast B, Stables RH; North West Quality Improvement Programme in Cardiac Interventions (NWQIP): Multivariate prediction of major adverse cardiac events after 9,914 percutaneous coronary interventions in the north west of England. Heart 2006;92:658-663.

23 Edwards AG, Teoh M, Hodges RJ, Palma-Dias R, Cole SA, Fung AM, Walker SP: Balancing patient access to fetoscopic laser photocoagulation for twin-to-twin transfusion syndrome with maintaining procedural competence: are collaborative services part of the solution? Twin Res Hum Genet 2016;19:276-284.

24 Lindenburg IT, Wolterbeek R, Oepkes D, Klumper FJ, Vandenbussche FP, van Kamp IL: Quality control for intravascular intrauterine transfusion using cumulative sum (CUSUM) analysis for the monitoring of individual performance. Fetal Diagn Ther 2011; 29:307-314.

25 Morris RK, Selman TJ, Harbidge A, Martin WI, Kilby MD: Fetoscopic laser coagulation for severe twin-to-twin transfusion syndrome: factors influencing perinatal outcome, learning curve of the procedure and lessons for new centres. BJOG 2010;117: 1350-1357.

26 American College of Obstetricians and Gynecologists, Society for Maternal-Fetal Medicine; Menard MK, Kilpatrick S, Saade G, Hollier LM, Joseph GF Jr, Barfield W, Callaghan W, Jennings J, Conry J: Levels of maternal care. Am J Obstet Gynecol 2015;212:259-271.

27 Huesch MD, Sakakibara M: Forgetting the learning curve for a moment: how much performance is unrelated to own experience? Health Econ 2009; 18:855-862. 